\title{
Studies on Fungi Responsible for the Spoilage/Deterioration of Some Edible Fruits and Vegetables
}

\author{
Iniekong P. Udoh ${ }^{1}$, Clara I. Eleazar ${ }^{1}$, Bryan O. Ogeneh ${ }^{2}$, Martin E. Ohanu ${ }^{1}$ \\ ${ }^{1}$ University of Nigeria, Enugu Campus, Nsukka, Nigeria \\ ${ }^{2}$ University of Oye, Eketi, Nigeria \\ Email: "lilyphils2004@yahoo.com
}

Received 26 March 2015; accepted 22 April 2015; published 24 April 2015

Copyright (C) 2015 by authors and Scientific Research Publishing Inc.

This work is licensed under the Creative Commons Attribution International License (CC BY). http://creativecommons.org/licenses/by/4.0/

(c) (i) Open Access

\begin{abstract}
Investigation of fungi responsible for the post harvest deterioration of Lycopersicum esculentus (tomatoes), Elaeis guineensis (palm fruit), Ipomoea batatas (sweet potato), Solanum tuberosum (Irish potato), Musa sapientum (banana), Doucus carota (carrot), Musa paradisiaca (plantain), Carica papaya (pawpaw), Persea americana (Avocado pear), Citrullus lanatus (water-melon) and Capsicum chinense (fresh red pepper) from five different markets and farm lands in Enugu state, Nigeria was carried out. Healthy and diseased samples were collected from the selected markets/ farmlands. Fungal species found associated with the deterioration of the various fruits and vegetables tested included Mucor species (M. indicus, M. amphibiorum, M. racemosus and M. hiemalis), Rhizopus species (Rhizopus stolonifer, R. nigrican and R. oligosporus), Candida albicans, Aspergillus species (Aspergillus fumigatus, $A$. niger and $A$. flavus) and Penicillum species (P. oxalicum and $P$. chrysogenum) and Fusarium species ( $F$. accuminatum, F. oxysporum, $F$. eqiuseti and $F$. moniliforme, $F$. solani, $F$. dimerum). All isolated fungi were pathogenic to the different fruits and vegetables from the result of pathogencity tests carried out.
\end{abstract}

\section{Keywords}

Fungi, Spoilage, Infection, Fruit, Vegetables

\section{Introduction}

Fungi are increasingly implicated as the agents of spoilage of economically important fruits and vegetables.

\footnotetext{
*Corresponding author.
} 
Fruits supply some necessary nutritional substances such as vitamins and essential minerals in human daily diet; this keeps the body in a good and healthy condition [1]. Consumption of fruit and vegetable products has dramatically increased in Nigeria by more than $40 \%$ during the past few decades. It is also estimated that about $30 \%$ of all fruits and vegetables produced is lost each year due to spoilage.

The prevalence of fungi as the spoilage organism of some edible fruits and vegetables abound in different locations in Nigeria. Fruits and vegetables are exposed to contamination by microorganisms through direct contact with soil, dust, water and by handling at harvest or during postharvest processing. This makes them to harbour a wide range of microorganisms including plant and human pathogens [2]. Microorganisms responsible for spoilage of fruits and vegetables exploit the host using extracellular lytic enzymes that degrade these polymers to release water and the plant's other intracellular constituents for use as nutrients for their growth. Fungi in particular produce an abundance of extracellular pectinases and hemicellulases that are important factors for fungal spoilage [3]. Some spoilage microbes are capable of colonizing and creating lesions on healthy, undamaged plant tissue [4].

Improper pre-harvest fungicide application, poor washing, and/or inadequate culling of fruits and vegetables usually lead to expanding infestation of spoilage microorganisms which can destroy a substantial portion of a stored lot of fruits [3]. The objective of the present study was to investigate and document the prevalence of fungi responsible for the spoilage of some fruits and vegetables in Enugu State, Nigeria.

\section{Materials and Methods}

\subsection{Sampling}

The specimens used in this study were obtained from various 3000 fruits and vegetables within Enugu State. Fungal isolates were obtained from ramdomly selected symptomatic plants (decaying or rotting plant substrate) such as L. esculentus (tomatoes), E. guineensis (palm fruit), I. batatas (sweet potato), S. tuberosum (Irish potato), M. sapientum (banana), D. carota (carrot), M. paradisiaca (plantain), C. papaya (pawpaw), P. americana (Avocado pear), C. lanatus (water-melon) and C. chinense (fresh red pepper) from five different markets and farm lands in Enugu state, Nigeria. The various sample parts used were L. esculentum (tomatoes)-fibrous skin and interior flesh, E. guineensis (palm fruit)—fibrous skin, I. batatas (sweet potato)— the peel and the inner tuber, $S$. tuberosum (Irish potato) - the fruit peel and the yellow pulp, M. sapientum (banana)-the fruit peel and the yellow pulp, D. carota (carrot)- the peel and the inner tuber, $M$. paradisiaca (plantain)-the fruit peel and the yellow pulp, C. papaya (pawpaw) - Juicy, sweet interior flesh, P. americana (Avocado pear)—juicy, sweet interior flesh, C. lanatus (water-melon)-juicy, sweet interior flesh and C. chinense (fresh red pepper).

The samples were distributed as follows: tomato seedlings-640, palm fruit-520, sweet potato-300, Irish potato-420, banana-200, carrot-150, plantain-210, pawpaw-120, avocado pear-100, water-melon-140, and pepper-200.

\subsection{Fungal Isolation}

Infected fruit and vegetable samples were first surface sterilized by washing under running tap water in order to remove dirt and sand. The infected portions of the various samples were excised and cut into $2 \mathrm{~mm}^{2}$ pieces with a flamed surgical blade, surface sterilized with $1 \% \mathrm{NaOCl}$ and rinsed in 4 successive changes of sterile distilled water. The excised infected portions were then plated on to Sabouraud dextrose agar (SDA) slants supplemented with $50 \mathrm{mg}$ chloramphenicol and $5 \mathrm{mg}$ gentamicin per liter. The cultures were incubated for 1 week under alternating 12-hour light and dark periods at $28^{\circ} \mathrm{C}$. Positive fungal cultures were examined under a stereo binocular microscope. The identity of these fungi was certified using cultural, morphological, pathogenicity tests as well as comparing them with confirmed representatives of the different species. This was according to modified method of Ewekeye et al. [1].

\section{Result}

Fungi found associated with the spoilage of pawpaw in this study were A. niger, A. flavus, R. nigra, R. oryzae, $M$. indicus, $M$. racemosus, $C$. albicans, $P$. oxalicum, $P$. digitatum, F. accuminatum, $R$. stolonifer and $R$. nigrican, while $R$, stolonifer, A. niger, F. accuminatum, F. oxysporum, F. eqiuseti, F. moniliforme, and F. solani were responsible for the soft rot of tomato. A. niger, A. flavus, A. fumigatus, $M$. indicus, $R$. nigrican, $R$. nigra and $F$. 
accuminatum were responsible for the spoilage of Irish potato. M. indicus, M. amphibiorum, M. racemosus, A. niger, A. flavus, A. fumigatus, F. accuminatum, F. oxysporum, R. nigrican, $R$. oligosporus and $R$. stolonifer were associated with carrot. Fungi involved in the deterioration of sweet potato were $F$. oxysporium and $F$. moniliforme, A. niger, A. flavus, A. fumigatus, M. racemosus, M. hiemalis, C. albicans, and P. oxalicum, while F. accuminatum, $R$. stolonifer and A. niger were found associated with the post-harvest deteriorating of water-melon. Penicillium expansum, $M$. indicus, $R$. nigrican and $F$. moniliforme were responsible for the spoilage of avocado pear, while $F$. oxysporium, F. moniliforme, $M$. indicus and $R$. nigrican were fungi found associated with the spoilage of banana and plantain. Fungi associated with the spoilage of palm fruit were F. accuminatum, F. moniliforme, F. oxysporium, A. niger, A. flavus, A. fumigatus, $M$. indicus, $M$. racemosus, $M$. hiemalis, $R$. nigrican, $R$. stolonifer and that responsible for the spoilage of pepper were F. oxysporium, F. dimerum, A. niger, M. amphibiorum, M. racemosus, $R$. oligosporus and $R$. stolonifer.

A total of 2140 (71.3\%) positive fungi isolates are recorded in Table 1 as follows: L. esculentus 410 (19.2\%), E. guineensis 415 (19.4\%), I. batatas 200 (9.3\%), S. tuberosum, 380 (17.8\%), M. sapientum 120 (5.6\%), D. carota 110 (5.1\%), M. paradisiaca 115 (5.4\%), C. papaya 78 (3.6\%), P. americana 67 (3.1\%), C. lanatus 110 (5.1\%) and C. chinense 135 (6.3\%). The rates of isolation of the 6 different genera from the various samples are displayed in Tables 2-4. Figure 1 shows the distribution of the fungi species responsible for the spoilage/soft rots as follows: A. niger (20.42\%), F. accuminatum (12.57), F. oxysporum (11.59\%), R. nigrican (9.77\%), F. moniliforme (6.92\%), M. indicus (6.40\%), R. stolonifer (6.03\%), A. flavus( 4.95\%), A. fumigatus (4.11\%), $M$. racemosus (3.46\%), M. hiemalis (3.08\%), $R$. nigra (1.78\%), M. amphibiorum (1.68\%), F. eqiuseti (1.68\%), $F$. solani (1.31\%), P. oxalicum (1.26\%), F. dimerum (0.97\%), C. albicans (0.93\%), R. oligosporus (0.84\%), P. expansum $(0.51 \%)$, R. oryzae $(0.28 \%)$ and P. digitatum $(0.19 \%)$.

\section{Discussion}

The high rate of isolation of fungi species from some edible fruits and vegetables in this study showed that fungi are responsible for post harvest deterioration of some edible fruits and vegetables in Enugu Nigeria. This is in line with the work of Akinmusire [5], who also in his studies in Maiduguri, Northern Eastern Nigeria revealed the prevalence of fungi as the spoilage organism of some edible fruits and vegetables Fusarium oxysporium and Fusarium moniliforme were among other fungi isolated. This result is in conformity with that of Olufunmilayo and Oyefolu [6], who reported natural occurrence of aflatoxin residues in fresh and sun-dried meat in Nigeria and further confirmed that meat generally sold in Nigeria are grossly contaminated by various fungi species including the potentially mycotoxigenic ones, such as Fusarium species. Amusa et al. [7] investigated the etiology of pre-harvest deterioration of Soursop (Annona muricata) fruit in Ibadan, southwestern Nigeria and the effects

Table 1. Rate of fungi isolated from the various vegetable and fruit samples.

\begin{tabular}{|ccc|}
\hline Fruit and Vegatable Samples & Number of Fungi Isolates (f) & Rate of Fungi Isolates (\%) \\
\hline E. guineensis (Palm fruit) & 415 & 19.4 \\
L. esculentus (Tomatoes) & 410 & 19.2 \\
S. tuberosum (Irish potato) & 380 & 9.3 \\
I. batatas (Sweet potato) & 200 & 6.3 \\
C. chinense (fresh red pepper) & 135 & 5.6 \\
M. sapientum (Banana) & 120 & 5.4 \\
M. paradisiaca (Plantain) & 115 & 5.1 \\
D. carota (Carrot) & 110 & 5.1 \\
C. lanatus (Water melon) & 110 & 3.6 \\
C. papaya (Pawpaw) & 78 & 3.1 \\
P. americana (Avocado pear) & 67 & 100 \\
Total Number/Rate of Isolates & 2140 & 5.3 \\
\hline
\end{tabular}


Table 2. Distribution of the fusarium and candida species within the samples.

\begin{tabular}{|c|c|c|c|c|c|c|c|c|c|c|c|}
\hline Fungi & $\begin{array}{c}L . \\
\text { esculentus }\end{array}$ & $\begin{array}{c}E . \\
\text { guineensis }\end{array}$ & $\begin{array}{c}\text { I. } \\
\text { batatas }\end{array}$ & $\begin{array}{c}S . \\
\text { tuberosum }\end{array}$ & $\begin{array}{c}M . \\
\text { sapientum }\end{array}$ & $\begin{array}{c}D . \\
\text { carota }\end{array}$ & $\begin{array}{c}\text { M. } \\
\text { paradisiaca }\end{array}$ & $\begin{array}{c}P . \\
\text { Americana }\end{array}$ & $\begin{array}{c}C . \\
\text { chinense }\end{array}$ & $\begin{array}{c}\text { C. } \\
\text { papaya }\end{array}$ & $\underset{\text { lanatus }}{C .}$ \\
\hline F. dimerum & 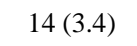 & ) (م) & $0(0.0)$ & $0(0.0)$ & $0(0.0)$ & $0(0.0)$ & $(0.0)$ & 0) & $10(7$ & $0(0.0)$ & $0(0.0)$ \\
\hline F. accuminatum & 34 (8.29) & $71(17.11)$ & $0(0.0)$ & $62(16.31)$ & $0(0.0)$ & 7 (6.36) & ) & $0(0.0)$ & $22(16.30)$ & $6(7.69)$ & 67 (60.91) \\
\hline F. oxysporum & $64(15.61)$ & 92 (22.17) & 21 (10.5) & $0(0.0)$ & 27 (22.5) & 12 (10.91) & $24(20.87)$ & $0(0.0)$ & $0(0.0)$ & $0(0.0)$ & $0(0.0)$ \\
\hline F. eqiuseti & 36 (8.78) & 0 & $0(0.0)$ & 0 & 0 & 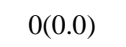 & 0 & ) & 0) & 0) & $0(0.0)$ \\
\hline F. moniliforme & $29(7.1)$ & $32(7.71)$ & 35 (17.5) & $0(0.0)$ & $18(15.0)$ & $0(0.0)$ & $22(19.13)$ & 15 (22.39) & $0(0.0)$ & $0(0.0)$ & $0(0.0)$ \\
\hline F. solani & $14(3.4)$ & $0(0.0)$ & $14(7.0)$ & $0(0.0)$ & $0(0.0)$ & $0(0.0)$ & $0(0.0)$ & $0(0.0)$ & $0(0.0)$ & $0(0.0)$ & $0(0.0)$ \\
\hline C. albicans & $0(0.0)$ & $0(0.0)$ & $17(8.5)$ & 46 (12.11) & $0(0.0)$ & $0(0.0)$ & $0(0.0)$ & $0(0.0)$ & $0(0.0)$ & $0(0.0)$ & $0(0.0)$ \\
\hline
\end{tabular}

Table 3. Distribution of the aspegilus and penicillium species in the samples.

\begin{tabular}{|c|c|c|c|c|c|c|c|c|c|c|c|}
\hline Fungi & $\begin{array}{c}L . \\
\text { esculentus }\end{array}$ & $\begin{array}{c}E . \\
\text { guineensis }\end{array}$ & $\begin{array}{c}I . \\
\text { batatas }\end{array}$ & $\begin{array}{c}S . \\
\text { tuberosum }\end{array}$ & $\begin{array}{c}M . \\
\text { sapientum }\end{array}$ & $\begin{array}{c}D . \\
\text { carota }\end{array}$ & $\begin{array}{c}\text { M. } \\
\text { paradisiaca }\end{array}$ & $\begin{array}{c}P . \\
\text { Americana }\end{array}$ & $\begin{array}{c}C . \\
\text { chinense }\end{array}$ & $\begin{array}{c}\text { C. } \\
\text { papaya }\end{array}$ & $\begin{array}{c}C . \\
\text { lanatus }\end{array}$ \\
\hline A. niger & 155 (37.80) & $89(21.45)$ & $31(15.50)$ & $8(21.30)$ & $0(0.0)$ & $11(10.0)$ & $0(0.0)$ & $0(0.0)$ & 35 (25.92) & 13 (16.67) & $22(20.0)$ \\
\hline A. flavus & $0(0.0)$ & $15(3.61)$ & $15(7.5)$ & $64(16.84)$ & $0(0.0)$ & 8 (7.27) & $0(0.0)$ & $0(0.0)$ & $0(0.0)$ & $4(5.13)$ & $0(0.0)$ \\
\hline A. fumigatus & $5 \quad 0(0.0)$ & 12 (2.89) & $16(8.0)$ & $51(13.42)$ & $0(0.0)$ & 9 (8.18) & $0(0.0)$ & $0(0.0)$ & $0(0.0)$ & $0(0.0)$ & $0(0.0)$ \\
\hline P. oxalicum & $0(0.0)$ & $0(0.0)$ & $22(11.0)$ & $0(0.0)$ & $0(0.0)$ & $0(0.0)$ & $0(0.0)$ & $0(0.0)$ & $0(0.0)$ & $5(2.5)$ & $0(0.0)$ \\
\hline P. digitatum & $0(0.0)$ & $0(0.0)$ & $0(0.0)$ & $0(0.0)$ & $0(0.0)$ & $0(0.0)$ & $0(0.0)$ & $0(0.0)$ & $0(0.0)$ & $4(5.13)$ & $0(0.0)$ \\
\hline P. expansum & $0(0.0)$ & $0(0.0)$ & $0(0.0)$ & $0(0.0)$ & $0(0.0)$ & $0(0.0)$ & $0(0.0)$ & $11(16.42)$ & $0(0.0)$ & $0(0.0)$ & $0(0.0)$ \\
\hline
\end{tabular}

Table 4. Distribution of the mucor and rhizopus species within the samples.

\begin{tabular}{|c|c|c|c|c|c|c|c|c|c|c|c|}
\hline Fungi & $\begin{array}{c}\text { L. } \\
\text { esculentus }\end{array}$ & $\begin{array}{c}E . \\
\text { guineensis }\end{array}$ & $\begin{array}{c}I . \\
\text { s batatas }\end{array}$ & $\begin{array}{c}S . \\
\text { tuberosum }\end{array}$ & $\begin{array}{c}\text { M. } \\
\text { sapientum }\end{array}$ & $\begin{array}{c}D . \\
\text { carota }\end{array}$ & $\begin{array}{c}M . \\
\text { paradisiaca }\end{array}$ & $\begin{array}{c}P . \\
\text { Americana }\end{array}$ & $\begin{array}{c}C . \\
\text { chinense }\end{array}$ & $\begin{array}{c}\text { C. } \\
\text { papaya }\end{array}$ & $\begin{array}{c}C . \\
\text { lanatus }\end{array}$ \\
\hline I. amphibiorum & (n) & $0(0.0)$ & $0(0.0)$ & $0(0.0)$ & $0(0.0)$ & $11(10.0)$ & $0(0.0)$ & $0(0.0)$ & $0(0.0)$ & $0(0.0)$ & $0(0.0)$ \\
\hline M. hiemalis & $0(0.0)$ & $14(\varepsilon$ & $4(2.0)$ & $0(0.0)$ & $(0.0)$ & $0(0.0)$ & $0(0.0)$ & $0(0.0)$ & 22 (16.30) & 6 (7.69) & $(0.0)$ \\
\hline M. inc & 0 & 17 (5.10) & $0(0.0)$ & $43(11.31)$ & $29(24.17)$ & 11 & 27 (23.48) & $13(19$. & $(0.0)$ & 9 (11.54) & $0(0.0)$ \\
\hline M. racemosus & $0(0.0)$ & $18(4.34)$ & 25 (12.5) & $0(0.0)$ & $0(0.0)$ & 10 (9.09) & $0(0.0)$ & $0(0.0)$ & 18 (13.33) & 6 (7.69) & $0(0.0)$ \\
\hline R. nigra & $0(0.0)$ & $0(0.0)$ & $0(0.0)$ & $30(8.90)$ & $0(0.0)$ & $0(0.0)$ & $0(0.0)$ & $0(0.0)$ & $0(0.0)$ & $8(18.26)$ & $0(0.0)$ \\
\hline R. nigrican & $0(0.0)$ & $23(5$ & $0(0.0)$ & $32(8.42)$ & $46(12.11)$ & $\begin{array}{c}13 \\
(11.82)\end{array}$ & $42(36.52)$ & 28( & $16(11.85)$ & $\begin{array}{c}11 \\
(14.10)\end{array}$ & $0(0.0)$ \\
\hline R. oligosporus & $0(0.0)$ & $0(0.0)$ & $0(0.0)$ & $0(0.0)$ & $0(0.0)$ & $6(5.45)$ & $0(0.0)$ & 0( & 12 & $0(0.0)$ & $0(0.0)$ \\
\hline R. oryzae & $0(0.0)$ & $0(0.0)$ & $0(0.0)$ & $0(0.0)$ & $0(0.0)$ & $0(0.0)$ & $0(0.0)$ & $0(0.0)$ & $0(0.0)$ & 6 (7.69) & $0(0.0)$ \\
\hline R. stolonifer & $64(15.61)$ & 12 (2.89) & $0(0.00)$ & $0(0.0)$ & $0(0.0)$ & 12 (11.0) & $0(0.0)$ & $0(0.0)$ & $0(0.0)$ & $0(0.0)$ & $\begin{array}{c}21 \\
(19.09)\end{array}$ \\
\hline
\end{tabular}

on its nutrient composition and found that, four fungal pathogens including Botryodiplodia theobromae, Fusarium sp., $R$. stolonifer and $A$. niger were found associated with the pre-harvest deteriorating soursop. This result further confirmed the findings of the present study where similar fungi were isolated and found to be responsible for the spoilage of some edible fruits and vegetable.

Gupta and Pathak [8], reported that A. niger, Aspergillus flavus, R. nigra, C. lanata, R. oryzae, F. eqiuseti and F. moniliforme were responsible for post harvest losses of pawpaw in south western Nigeria. Oke and Banjoko 


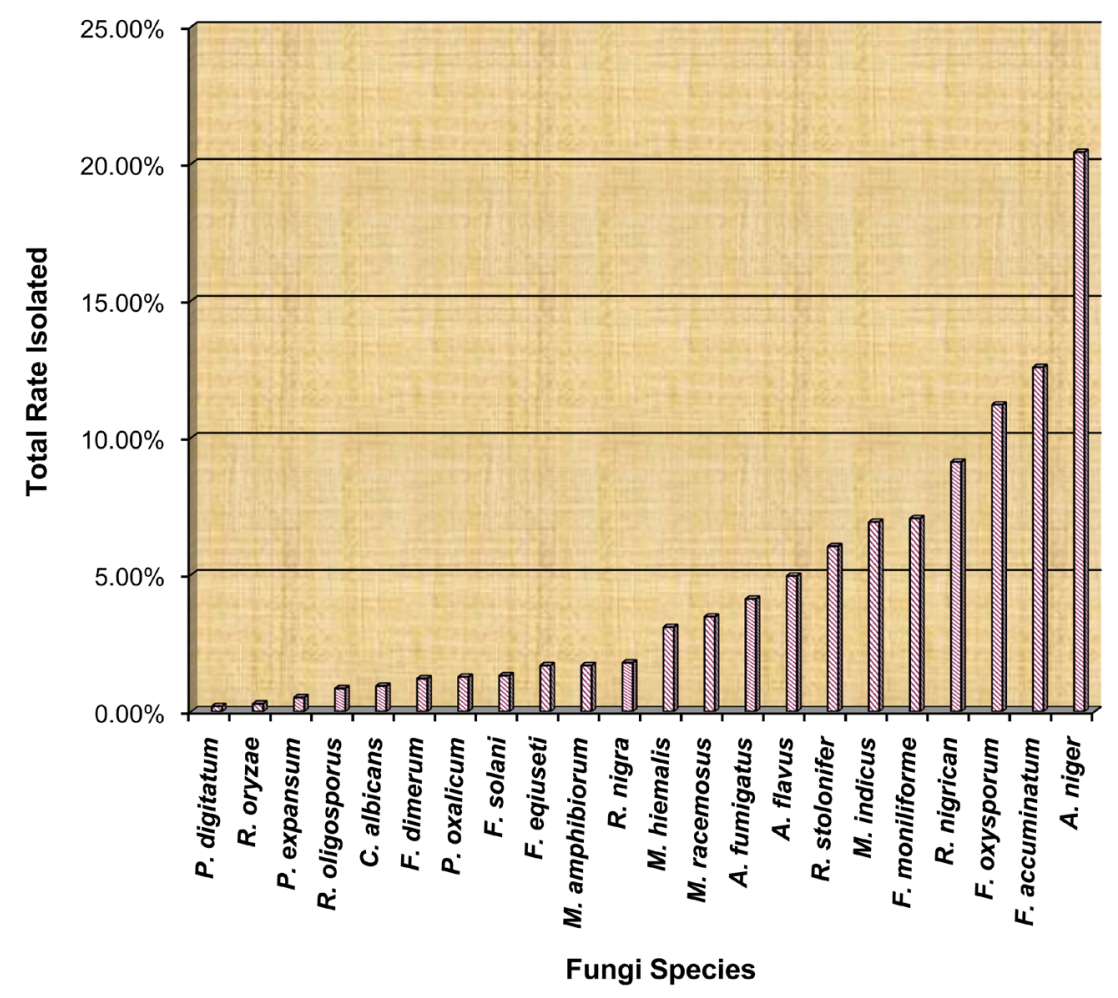

Figure 1. Total distribution rate of the fungi species.

[9] have also reported P. digitatum and F. oxysporium on pawpaw. This is consistent with the result of the present study where these fungi were also seen to be responsible for deterioration of pawpaw fruits. Different fungal species have been reported to be associated with the post harvested deterioration of these fruits and vegetables in different locations.

Losses due to post harvest spoilage or pathological decay are result of latent infections in the field that become active following harvest or of crosses contamination during harvest, cleaning, storage, and distribution. Presence of the pathogen on a susceptible host fruit or vegetable, combined with suitable environmental conditions such as high temperature, provides the three components required for disease expression such as host, environment, and pathogen.

During harvest and handling before storage and distribution, it is important to minimize wounds and bruising and to cull all damaged and diseased product. A few spoilage microbes, primarily fungi, can infect healthy tissues by forming appressoria, external structures that enable the pathogen to penetrate the cuticle and epidermis. The developing appressorium ramifies through these protective layers and into the pulp through a combination of mechanical pressure and tissue destruction by extracellular enzymes. However, most spoilage microbes infect and initiate decay at punctures and splits in the epidermal layer or, in far fewer cases, through natural openings such as stomata and lenticels.

\section{Conclusion}

Deterioration of most fruits and vegetable is caused by fungi infection. We therefore recommended timely spraying of the fruits with fungicides to reduce the damaging activities of the fungal pathogen and contamination with mycotoxins and other related fungal metabolites that might be harzadous to human health. Since some of these pathogens gain access via wounds created by insect pests, there is also the need for further investigations of the pests causing injuries on fruits, with the aims of reducing their activities.

\section{References}

[1] Ewekeye, T.S., Oke, O.A., Quadri, A.I., Isikalu, A.O., Umenwaniri, M.O. and Durosinmi, M.L. (2013) Studies on Post 
Harvest Deterioration of Some Fruits and Vegetables in Selected Markets in Lagos State, Nigeria. American Journal of Research Communication, 1, 209-222. www.usa-journals.com

[2] Eni, A.O., Oluwawemitan, T.O. and Solomon O.U. (2010) Microbial Quality of Fruits and Vegetables Sold in Sango Ota, Ogun State, Nigeria. African Journal of Food Science, 4, 291-296.

[3] Miedes, E. and Lorences, E.P. (2004) Apple (Malus domestica) and Tomato (Lycopersicum esculentum) Fruits CellWall Hemicelluloses and Xyloglucan Degradation during Penicillium Expansum Infection. Journal of Agricultural and Food Chemistry, 52, 7957-7963. http://dx.doi.org/10.1021/jf048890f

[4] Tournas, V.H. (2005) Spoilage of Vegetable Crops by Bacteria and Fungi and Related Health Hazards. Critical Review of Microbiology, 31, 33-44. http://dx.doi.org/10.1080/10408410590886024

[5] Akinmusire, O.O. (2011) Fungal Species Associated with the Spoilage of Some Edible Fruits in Maiduguri Northern Eastern Nigeria. Advances in Environmental Biology, 5, 157-161.

[6] Olufunmilayo, G.O. and Oyefolu, A.B. (2010) Natural Occurrence of Aflatoxin Residues in Fresh and Sun-Dried Meat in Nigeria. The Pan African Medical Journal, 7, 14.

[7] Amusa, N.A., Ashaye, O.A., Oladapo, M.O. and Kafaru, O.O. (2003) Pre-Harvest Deterioration of Sour Sop (Annona muricata) at Ibadan Southwestern Nigeria and Its Effect on Nutrient Composition. African Journal of Biotechnology, 2, 23-25. http://dx.doi.org/10.5897/AJB2003.000-1004

[8] Gupta, A.K. and Pathak, V.N. (1986) A Survey of Fruit Market for Papaya Fruit Rot by Fungal Pathogens. Indian Mycology Journal, 10, 152-154.

[9] Oke, O.A. and Banjoko, K.M. (1991) The Effect of Penicillium digitatum and Fusarium oxysporium Rot Infections on Nutritional Content of Pawpaw. Mycopathologia, 116, 199-201. http://dx.doi.org/10.1007/BF00436835 